\title{
Extrapontine myelinolysis: rare manifestation of a well-known disorder
}

\author{
Jyoti Wadhwa, ${ }^{1}$ Ramesh Ananthakrishnan, ${ }^{2}$ Srikant Sadashiv, ${ }^{1}$ Abdoul Hamide ${ }^{1}$
}

${ }^{1}$ Department of Medicine, Jawaharlal Institute of Postgraduate Medical Education and Research (JIPMER), Pondicherry, India ${ }^{2}$ Department of

Radiodiagnosis, Jawaharlal Institute of Postgraduate Medical Education and Research (JIPMER), Pondicherry, India

\section{Correspondence to} Professor Abdoul Hamide, hamidmk@yahoo.com

\section{-}

To cite: Wadhwa J, Ananthakrishnan $\mathrm{R}$, Sadashiv S, et al. BMJ Case Rep Published online: [please include Day Month Year] doi:10.1136/bcr-2013200808

\section{DESCRIPTION}

A young alcoholic male patient was referred from another hospital with a history of loose stools and vomitings. There was documentation of hyponatraemia $(\mathrm{Na}-111 \mathrm{mEq} / \mathrm{L})$ which was treated with intravenous normal saline. Next day, sodium was documented to be $134 \mathrm{mEq} / \mathrm{L}$. On the third day, the patient had worsening of sensorium and was referred to our department for further management.

On presentation, the patient was comatose and had sluggishly reactive pupillary reflexes.

His MRI (figure 1) showed symmetrical hyperintensity in bilateral caudate and putamen nuclei with globus pallidus and pontine sparing consistent with extrapontine myelinolysis. The patient had rapid worsening course in our hospital and expired on the same day.

Osmotic demyelination syndrome (ODS) was first described by Adams et $a l^{1}$ in alcoholics and malnourished patients. In ODS, demyelination is usually present within the central basis pontis (central pontine myelinolysis) or maybe found in the midbrain, thalamus, basal ganglia and cerebellum (extrapontine myelinolysis). Extrapontine lesions may accompany the pontine lesions in $10 \%$ of the cases.

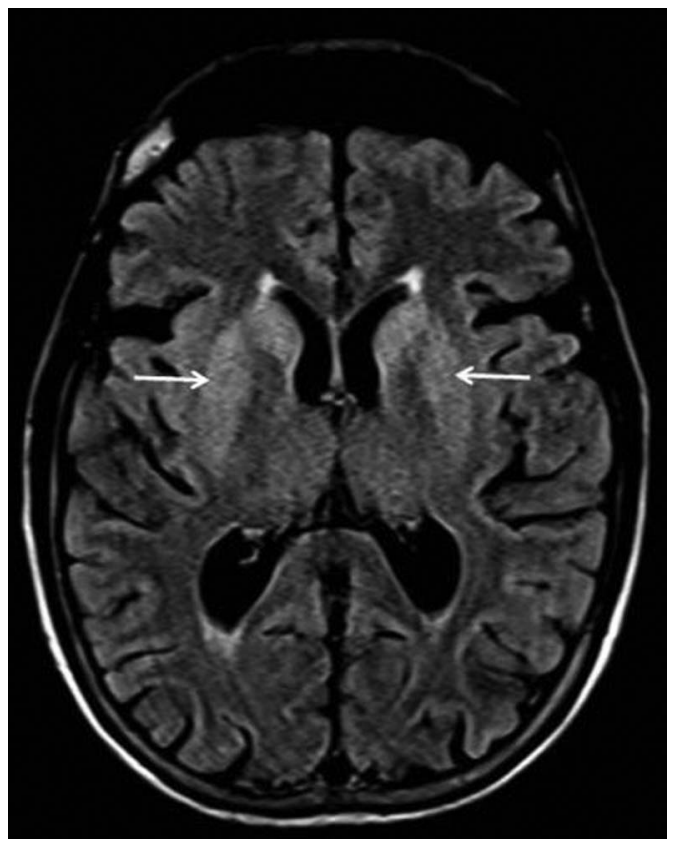

Figure 1 Axial fluid-attenuated inversion recovery MRI showing symmetrical hyperintensity in bilateral caudate and putamen nuclei (arrows) with globus pallidum sparing.
Risk factors associated with ODS include rapid correction of hyponatremia, alcoholism, malnutrition, liver disease and liver transplant. ${ }^{2}$

As seen in our case, patients with hypovolemic hyponatraemia tend to have a rapid increase in plasma $\mathrm{Na}^{+}$concentration with saline therapy. This happens because of a rapid fall of arginine vasopressin levels with intravenous saline resulting in water diuresis. Hence sodium levels should be monitored frequently $(2-4 \mathrm{~h})$ to guide further saline therapy. Furthermore, his alcoholic status might have predisposed him for ODS.

ODS is usually associated with poor prognosis though a few case reports ${ }^{3}$ have suggested better outcome after IVIG administration.

\section{Learning points}

- Extrapontine myelinolysis is characterised by demyelinating lesions in basal ganglia, thalamus, cerebellum and midbrain with pontine and pallidal sparing.

- In patients with hypovolaemic hyponatraemia, volume repletion causes a rapid fall in arginine vasopressin levels resulting in large water diuresis, which can lead to a more rapid correction of hyponatraemia than desired.

- Sodium levels should be frequently monitored (2-4 h) while managing a case of hyponatraemia, and sodium correction should not exceed 8-10 mmol/day.

Contributors JW drafted the article and performed related literature search. RA described the image findings and also revised the article. SS was involved in data collection and $\mathrm{AH}$ contributed to the article drafting and revision.

Competing interests None.

Patient consent Obtained.

Provenance and peer review Not commissioned; externally peer reviewed.

\section{REFERENCES}

1 Adams RD, Victor M, Mancall EL. Central pontine myelinolysis: a hitherto undescribed disease occurring in alcoholic and malnourished patients. AMA Arch Neurol Psychiatry 1959;81:154-72

2 Singh N, Yu VL, Gayowski T. Central nervous system lesions in adult liver transplant recipients: clinical review with implications for management. Medicine (Baltimore). 1994;73:110-18.

3 Finsterer J, Engelmayer E, Trnka E, et al. Immunoglobulins are effective in pontine myelinolysis. Clin Neuropharmacol 2000;23:110-13 
Copyright 2013 BMJ Publishing Group. All rights reserved. For permission to reuse any of this content visit http://group.bmj.com/group/rights-licensing/permissions.

BMJ Case Report Fellows may re-use this article for personal use and teaching without any further permission.

Become a Fellow of BMJ Case Reports today and you can:

- Submit as many cases as you like

- Enjoy fast sympathetic peer review and rapid publication of accepted articles

- Access all the published articles

- Re-use any of the published material for personal use and teaching without further permission

For information on Institutional Fellowships contact consortiasales@bmjgroup.com

Visit casereports.bmj.com for more articles like this and to become a Fellow 